\title{
Tanggung Jawab dan Kewenangan Perawat Gigi dalam Melakukan Tindakan Medik Kedokteran Gigi
}

\author{
Khoirul Anam \\ Kepala Instalasi Hukum dan Kemitraan Rumah Sakit dr. Dradjat Prawiranwgara, Serang \\ Email: khoirulanam31@gmail.com
}

\begin{abstract}
One health worker doing health efforts is a dental nurse. The authority of dental nurses to perform their work is the legal authority (rechtsbevoegheid). Legal authority is the authority possessed by a health worker to perform his work, so on the basis of authority, this is the dental nurse entitled to conduct treatment in accordance with the field of expertise. In this case, dental nurses have authority in the form of duty as dental nurse and dental duty of dentist and also from legislation in certain circumstance, based on Regulation of Minister of Health of Republic of Indonesia Number 20 Year 2016 about Permission and Practice of Dental and Oral Therapist Practice, that the dental nurse enters the nursing staff. Thus, dental nurses have authority in performing medical acts on the basis of legislation and delegation of some of the authority of the dentist. The research that is done is using. Sociological juridical research method (social-legal approach), this study was conducted in Salatiga City, Central Java Province. This type of data in scientific papers is in the form of primary data and secondary data is supported by tertiary data. The result of this research is the authority of dental nurse in doing the effort of nursing health service has two authority that is the authority of attribution and authority of delegation. Sanctions that can be given to dentists and dental nurses can be disciplinary, administrative, civil and criminal sanctions.
\end{abstract}

Keywords : jurisdiction, dental therapist, attribution and delegation

\begin{abstract}
Abstrak
Salah satu tenaga kesehatan yang melakukan upaya kesehatan adalah perawat gigi. Kewenangan perawat gigi untuk melakukan pekerjaannya adalah kewenangan hukum (rechtsbevoegheid). Kewenangan hukum yaitu kewenangan yang dimiliki oleh seorang tenaga kesehatan untuk melakukan pekerjaannya, sehingga atas dasar kewenangan, inilah perawat gigi berhak melakukan pengobatan sesuai dengan bidang keahliannya. Dalam hal ini perawat gigi memiliki kewenangan yang berupa tugas pokok sebagai perawat gigi dan tugas limpah dari dokter gigi maupun dari peraturan perundang-undangan dalam keadaan tertentu, berdasarkan Peraturan Menteri Kesehatan Republik Indonesia Nomor 20 Tahun 2016 tentang Izin dan Penyelenggaraan Praktik Terapis Gigi dan Mulut, bahwa perawat gigi masuk dalam tenaga keperawatan. Dengan demikian, perawat gigi memiliki kewenangan dalam melakukan tindakan medik atas dasar peraturan perundang-undangan dan pelimpahan sebagian kewenangan dokter gigi. Penelitian yang dilakukan yaitu menggunakan. Metode Penelitian yuridis Sosiologis (social-legal approach), penelitian ini dilakukan di Kota Salatiga, Propinsi Jawa Tengah. Jenis data dalam karya tulis ilmiah ini berupa data primer dan data sekunder di dukung dengan data tersier. Hasil dari penelitian ini adalah kewenangan perawat gigi dalam melakukan upaya pelayanan kesehatan keperawatan memiliki dua kewenangan yaitu kewenangan atribusi dan kewenangan delegasi. Sanksi yang bisa diberikan kepada dokter gigi maupun perawat gigi bisa berupa sanksi disiplin, administrasi, perdata dan pidana.
\end{abstract}

Kata kunci: kewenangan hukum, Terapis gigi, atribusi dan delegasi. 


\section{PENDAHULUAN}

Upaya pelayanan kesehatan yang dilakukan oleh tenaga kesehatan adalah kegiatan untuk memelihara dan meningkatkan kesehatan. Upaya pelayanan kesehatan yang dilakukan oleh pemerintah dan/atau masyarakat yang semula dititikberatkan pada upaya kuratif penderita berangsur-angsur berkembang ke arah keterpaduan antara promotif, preventif, kuratif dan rehabilitatif ${ }^{1}$. Tenaga kesehatan memberikan pelayanan kesehatan sesuai dengan standar profesi medik, standar pelayanan dan sesuai dengan kewenangannya, apa bila tenaga kesehatan melaksanakan pekerjaan tidak sesuai dengan kewenangannya maka tenaga kesehatan tersebut melanggar salah satu standar profesi tenaga kesehatan, karena di dalam standar profesi terdapat kewenangan masing-masing tenaga kesehatan.

Kewenangan tenaga kesehatan dalam memberikan pelayanan kesehatan merupakan kewenangan hukum ${ }^{2}$. Berdasarkan ilmu hukum administrasi negara, kewenangan yang bersumber dari peraturan perundang-undangan di peroleh melalui tiga cara yaitu atribusi, delegasi dan mandat. Mengenai atribusi, delegasi dan mandat, H.D. Van Wijk mendefinisikan sebagai berikut:

1) Atribusi adalah pemberian wewenang pemerintah oleh pembuat UndangUndang kepada organ pemerintah.

2) Delegasi adalah pelimpahan wewenang pemerintah dari satu organ pemerintah kepada organ pemerintah lainnya.

3) Mandat adalah terjadi ketika organ pemerintah mengizinkan kewenangannya dijalankan oleh organ lain atas namanya ${ }^{3}$.

Dalam Undang-Undang Nomor 36 Tahun 2009 Tentang Kesehatan Pasal 1 angka 6 mengatur:

\footnotetext{
Soewono,H., 2005, Batas Pertanggungjawaban Hukum Malpraktik Dokter Dalam Transaksi Terapeutik, Surabaya, Srikandi, Hal. 16-17.
}

\begin{abstract}
"Tenaga kesehatan adalah setiap orang yang mengabdikan diri dalam bidang kesehatan serta memiliki pengetahuan dan/atau keterampilan melalui pendidikan di bidang kesehatan yang untuk jenis tertentu memerlukan kewenangan untuk melakukan upaya kesehatan".
\end{abstract}

Definisi di dalam Pasal 1 angka 6 dalam Undang-Undang Nomor 36 Tahun 2009 Tentang Kesehatan sama dengan Pasal 1 angka 1 Peraturan Pemerintah Republik Indonesia Nomor 32 tahun 1996 Tentang Tenaga Kesehatan. Berdasarkan Pasal 1 angka 6 Undang-Undang Nomor 36 Tahun 2009 Tentang Kesehatan dan Pasal 1 angka 1 Peraturan Pemerintah Republik Indonesia Nomor 32 tahun 1996 Tentang Tenaga Kesehatan disebutkan bahwa tenaga kesehatan jenis tertentu untuk dapat melakukan upaya kesehatan memerlukan kewenangan, salah satunya perawat gigi.

Ketentuan lebih lanjut tentang pelimpahan kewenangan tindakan medik terbatas di bidang kedokteran gigi ini diatur dalam Peraturan Menteri Kesehatan Republik Indonesia Nomor 512/Menkes/Per/IV/2007 Tentang Izin Praktik dan Pelaksanaan Praktik Kedokteran, pada Pasal 15 yang isinya sebagai berikut:

(1) Dokter dan dokter gigi dapat memberikan pelimpahan suatu tindakan kedokteran atau kedokteran gigi kepada perawat, bidan atau tenaga kesehatan tertentu lainnya secara tertulis dalam melaksanakan tindakan kedokteran atau kedokteran gigi.

(2) Tindakan kedokteran atau kedokteran gigi sebagaimana dimaksud pada ayat (1) harus sesuai dengan kemampuan dan

\footnotetext{
${ }^{2}$ Wila Chandrawila Supriadi, 2001, Hukum Kedokteran, Bandung : Mandar Maju, hal. 52.

${ }^{3}$ Ridwan, 2003, Hukum Administrasi Negara, Cetakan II, Jakarta, UII press, Hal. 73-74.
} 
kompetensi yang dimiliki dan dilaksanakan sesuai ketentuan peraturan perundang-undangan.

(3) Pelimpahan wewenang kepada perawat, bidan atau tenaga lainnya dalam keadaan tertentu dimana pelayanan kesehatan sangat dibutuhkan dan tidak terdapat dokter dan dokter gigi di tempat tersebut diatur lebih lanjut dengan Peraturan Menteri .

Berdasarkan Peraturan Menteri Kesehatan Nomor 512 Tahun 2007 tersebut, maka dokter gigi dapat memberikan sebagian kewenangannya kepada perawat gigi yang diberikan secara tertulis dan harus sesuai dengan kemampuan pendidikan, kompetensinya serta sesuai dengan ketentuan peraturan perundang-undangan. Pada ayat (3) Peraturan Menteri Kesehatan Nomor 512 Tahun 2007, disebutkan bahwa dalam keadaan tertentu dimana pelayanan kesehatan sangan dibutuhkan dan tidak ada dokter gigi akan diatur lebih lanjut dengan Peraturan Menteri, sejauh penelitian ini dilakukan belum ada peraturan menteri yang mengatur tentang hal ini.

Tindakan medik yang dilakukan oleh perawat gigi, dengan berlakunya UndangUndang Nomor 29 Tahun 2004 Tentang Praktik kedokteran, disebutkan pada Pasal 73 sebagai berikut:

(1) Setiap orang dilarang menggunakan identitas berupa gelar atau bentuk lain yang menimbulkan kesan bagi masyarakat seolah-olah yang bersangkutan adalah dokter atau dokter gigi yang telah memiliki surat tanda registrasi dan/atau surat izin praktik.

(2) Setiap orang dilarang menggunakan alat, metode atau cara lain dalam memberikan pelayanan kepada masyarakat yang menimbulkan kesan seolah-olah yang bersangkutan adalah dokter atau dokter gigi yang telah memiliki surat tanda registrasi dan/atau surat izin praktik.

(3) Ketentuan sebagaimana dimaksud pada ayat (1) dan ayat (2) tidak berlaku bagi tenaga kesehatan yang diberi kewenangan oleh peraturan perundang-undangan.

Pada Pasal 73 Ayat (3) tersebut terlihat bahwa ada tenaga kesehatan yang diberi kewenangan oleh peraturan perundangundangan, pada penjelasan Pasal 73 ayat (3) disebutkan bahwa:

"Tenaga kesehatan dimaksud antara lain bidan dan perawat yang diberi kewenangan untuk melakukan tindakan medik sesuai dengan peraturan perundanganundangan".

Berdasarkan Undang-Undang Nomor 29 Tahun 2004 Pasal 73 Ayat (3) menunjukkan bahwa perawat gigi yang diberi kewenangan untuk melakukan tindakan medik terbatas di bidang kedokteran gigi, dan di dalam Permenkes Nomor 512 Tahun 2007 Pasal 15 ada sebagian kewenangan dokter gigi yang dapat dilimpahkan kepada perawat gigi, sehingga ke dua peraturan ini tidak bertentangan.

Peraturan perundang-undangan yang mengatur tentang kewenangan perawat gigi dalam melakukan tindakan medik terbatas dalam bidang kedokteran gigi adalah Peraturan Menteri Kesehatan Republik Indonesia Nomor 20 Tahun 2016 tentang Izin dan Penyelenggaraan Praktik Terapis Gigi dan Mulut. Apabila dilihat dari bentuknya, Peraturan Menteri Kesehatan ini tidak termasuk dalam peraturan perundangundangan, sebagaimana dimaksud dalam Pasal 7 ayat (1) Undang-Undang Nomor 12 Tahun 2011 Tentang Pembentukan Peraturan Perundang-Undangan, namun demikian apabila merujuk pada Pasal 7 ayat (4) UndangUndang Nomor 12 Tahun 2011 Tentang Pembentukan Peraturan Perundang-Undangan disebutkan:

$$
\begin{aligned}
& \text { "Jenis Peraturan } \\
& \text { Perundang- } \\
& \text { undangan selain }
\end{aligned}
$$


dimaksud pada ayat (1), diakui keberadaannya dan mempunyai kekuatan hukum mengikat sepanjang diperintahkan oleh Peraturan Perundang-undangan yang lebih tinggi".

Dalam Pasal 8 ayat (1) UndangUndang Nomor 12 Tahun 2011 Tentang Pembentukan Peraturan Perundang-Undangan disebutkan:

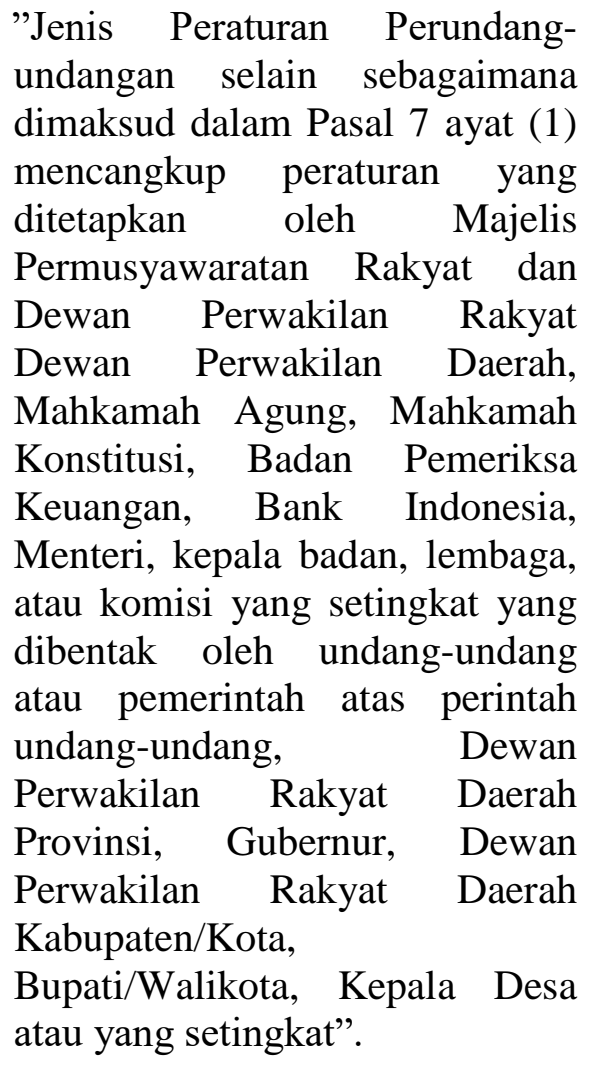

Pelaksanaan Peraturan Menteri Kesehatan Republik Indonesia Nomor 20 Tahun 2016 tentang Izin dan Penyelenggaraan Praktik Terapis Gigi dan Mulut, belum bisa dilaksanakan dengan baik dan masih banyak permasalahan antara lain seorang perawat gigi merasa bahwa dengan adanya Surat Keputusan Menteri Kesehatan ini mereka dapat melakukan tindakan medik dengan bebas, di lain pihak dokter gigi pun merasa bahwa semua perawat gigi bisa diberi sebagian kewenangannya untuk melakukan tindakan medik terbatas di bidang kedokteran gigi. Dalam keadaan yang lebih parah lagi seorang dokter gigi senior lebih percaya kepada perawat gigi senior dari pada dokter gigi yang baru lulus (fresh graduate) dalam hal melakukan tindakan-tindakan medik di sarana pelayanan kesehatan.

Setiap orang yang diberi kewenangan haruslah bertanggung jawab. Bertanggung jawab terhadap risiko yang kemungkinan timbul yang mengakibatkan terjadinya kerugian kepada pihak lain. Tanggung jawab sebagaimana juga risiko adalah sesuatu yang bersifat laten. Jika resikonya timbul dan terjadi tuntutan, maka barulah persoalan tanggung jawab dan kewenangan juga akan muncul ke permukaan. Tuntutan hukum dari pihak lain dalam hal ini pasien dapat disebabkan oleh malpraktik atau penyimpangan dari pelaksanaan tugasnya serta kurang menghormati hak pasien. Di sisi lain masyarakat semakin tinggi tingkat pengetahuan dan kesadaran hukumnya. Demikian pula Undang-Undang telah mewadahi perlindungan pasien sehingga kecenderungan masyarakat untuk melakukan tuntutan akibat penyimpangan tindakan dari tenaga kesehatan semakin tinggi pula.

Dalam praktik sehari-hari berdasarkan pengamatan dan pengalaman peneliti selama bekerja di Puskesma dan Dinas Kesehatan, dokter gigi atau perawat gigi secara umum belum dapat memahami tentang tugas limpah dari dokter gigi kepada perawat gigi dalam melakukan tindakan medik terbatas dalam bidang kedokteran gigi, khususnya di Kota Salatiga. Pemahaman tentang tugas limpah antara dokter gigi dan perawat gigi belum sesuai dengan peraturan perundang-undangan yang berlaku. Ada sebagian dokter gigi yang memahami tugas limpah ini adalah kewenangan perawat gigi, ada lagi yang memahami bahwa tugas limpah ini adalah kewenangan dokter gigi sehingga perawat gigi untuk melakukan kewenangan ini harus izin kepada dokter gigi. Demikian juga perawat gigi dalam memahami tugas limpah ini juga berbeda-beda, ada yang memahami tugas limpah ini menjadi kewenangan perawat gigi sehingga mereka boleh melakukan tindakan 
medik terbatas di bidang kedokteran gigi tanpa harus izin secara tertulis dari dokter gigi, ada juga yang tidak mengetahui apa yang dilakukan apakah tindakan keperawatan atau tindakan medik terbatas di bidang kedokteran gigi.

Pemahaman yang berbeda-beda juga terjadi antara dokter gigi dan perawat gigi tentang tindakan medik terbatas dalam bidang kedokteran gigi ini juga dalam hal siapa yang bertanggung jawab apabila terjadi kesalahan perawat gigi dalam melakukan tindakan medik terbatas ini. Ada yang memahami bahwa yang bertanggung jawab adalah perawat gigi karena dia yang melakukan tindakan ini ada juga yang berpendapat bahwa yang bertanggung jawab adalah dokter gigi karena yang bertanggung jawab di poli gigi dan mulut di Puskesmas adalah dokter gigi. Berdasarkan penjelasan di atas maka perlu adanya kajian yang lebih mendalam tentang kewenangan perawat gigi dalam melakukan tindakan medik terbatas menurut Peraturan Menteri Kesehatan Republik Indonesia Nomor 20 Tahun 2016 tentang Izin dan Penyelenggaraan Praktik Terapis Gigi dan Mulut di Puskesmas Kota Salatiga.

Dari penjelasan di atas maka penulis tertarik melakukan penelitian tentang pelaksanaan kewenangan perawat gigi dalam melakukan tindakan medik terbatas dalam bidang kedokteran gigi di Puskesmas di kota Salatiga dengan judul "Tanggung Jawab dan Kewenangan Perawat Gigi Dalam Melakukan Tindakan Medik Kedokteran Gigi”

Dari uraian latar belakang di atas, maka di susun perumusan masalah mengenai kewenangan perawat gigi dalam melakukan tindakan medik menurut Peraturan Menteri Kesehatan Republik Indonesia Nomor 20 Tahun 2016 tentang Izin dan Penyelenggaraan Praktik Terapis Gigi dan Mulut setelah berlakunya Undang-Undang Nomor 29 Tahun 2004 tentang Praktik Kedokteran serta pertanggungjawaban atas kesalahan yang dilakukan oleh perawat gigi dalam melakukan tindakan medik.

\section{METODE PENELITIAN}

Penelitian yang dilakukan yaitu menggunakan Metode Penelitian yuridis Sosiologis (social-legal approach) dimana penelitian dengan analisis pendekatan dengan menekankan pada aspek yuridis dan sekaligus membahas aspek-aspek sosial yang melingkupi gejala hukum tertentu, dalam hal ini adalah implementasi kewenagan perawat gigi dalam melakukan tindakan medik menurut Peraturan Menteri Kesehatan Republik Indonesia Nomor 20 Tahun 2016 tentang Izin dan Penyelenggaraan Praktik Terapis Gigi dan Mulut setelah berlakunya Undang-Undang Nomor 29 Tahun 2004 Tentang Praktik Kedokteran.

Penelitan ini dilakukan di 3 atau 50\% Puskesmas induk di Kota Salatiga. Pemilihan ke tiga Puskesmas ini berdasarkan kriteria sebagai berikut memiliki dokter gigi dan perawat gigi yang telah berstatus pegawai negeri sipil, jumlah kunjungan pasien setiap hari rata-rata diatas 10 pasien. Puskesmas pertama memiliki 2 dokter gigi dan 3 perawat gigi, Puskesmas ke dua memiliki 1 dokter gigi dan 1 perawat gigi, Puskesmas ke tiga memiliki 3 dokter gigi dan 2 perawat gigi. Puskesmas pertama dan ke tiga yang memiliki lebih dari satu dokter gigi dan perawat gigi maka di pilih satu dokter gigi dan perawat gigi dengan kriteria yang paling lama bekerja di Puskesmas.

Kewenangan perawat gigi jenjang diploma III dalam melakukan tindakan medik terbatas menurut Peraturan Menteri Kesehatan Republik Indonesia Nomor 20 Tahun 2016 tentang Izin dan Penyelenggaraan Praktik Terapis Gigi dan Mulut setelah berlakunya Undang-Undang Nomor 29 Tahun 2004 Tentang Praktik Kedokteran.

Jenis data dalam karya tulis ilmiah ini berupa data primer dan data sekunder di dukung dengan data tersier. Data primer adalah data yang diperoleh peneliti dari penelitian secara langsung di lapangan. Dalam hal ini dilakukan dengan cara observasi, wawancara dan daftar pertanyaan kepada para responden yang ada di puskesmas, Dinas 
Kesehatan Kota Salatiga dan pengurus organisasi profesi PDGI untuk dokter gigi atau PPGI untuk perawat gigi di Kota Salatiga. Data sekunder adalah data yang diperoleh dari kepustakaan dan data-data yang menunjang penelitian. Data sekunder berupa data tentang jumlah dokter gigi dan perawat gigi yang bekerja di Dinas Kesehatan Kota Salatiga, data jumlah penduduk, data jumlah dan susunan organisasi profesi dokter gigi dan data jumlah dan susunan organisasi profesi perawat gigi. Bahan hukum tersier, yaitu bahan yang memberikan petunjuk maupun penjelasan terhadap bahan hukum primer dan sekunder, contohnya adalah kamus dan ensiklopedia.

Dalam karya tulis ilmiah bidang ilmu hukum analisis data berupa analisis data kualitatif menggunakan peraturan yang ada dan teori hukum. Penyajian data diberikan secara deskriptif.

\section{KERANGKA KONSEPTUAL \\ 1. Perawat gigi}

Perawat (Nurse) berasal dari Bahasa Latin yaitu kata nutrix yang berarti merawat atau memelihara. Kata ini pertama kali digunakan oleh Ellis dan Hartly dalam Jumadi, yang menjelaskan pengertian dasar seorang perawat yaitu seseorang yang berperan dalam merawat dan memelihara, membantu dan melindungi seseorang karena sakit, cidera dan proses penuaan. Pengertian ini banyak digunakan perawat, meskipun pengertian ini belum mencangkup perkembangan peran dan fungsi perawat dewasa ini. Organisasi Keperawatan Sedunia atau International Council of Nurse atau disingkat dengan ICN mengadopsi definisi perawat dari Virgina Hendersen yang merumuskan fungsi perawat yaitu melaksanakan pengkajian pada individu sehat maupun sakit, dimana segala aktivitas yang dilakukan berguna untuk kesehatan dan pemulihan kesehatan

\footnotetext{
${ }^{4}$ La OdeJumadi G., 1999, Pengantar Keperawatan Profesional,Cetakan 1, Jakarta, EGC, Hal. 14-15.
}

berdasarkan pengetahuan yang dimilikinya ${ }^{4}$.

Secara umum perawat gigi termasuk dalam bidang profesi perawat profesional yang termasuk dalam bidang keperawatan. Sehingga dengan demikian perawat gigi setara dengan bidan dan perawat umum hal ini sesuai dengan Surat Keputusan Menteri kesehatan Nomor 1035/Menkes/SK/ IX/1998 Tentang Perawat Gigi.

Ada beberapa pengertian dari perawat gigi yang dapat dijadikan dasar yaitu:

1. Berdasarkan Surat Keputusan Menteri Kesehatan Nomor 1035 Tahun 1998 Tentang Perawat Gigi dinyatakan:

"Perawat gigi adalah setiap orang yang telah mengikuti dan menyelesaikan pendidikan perawat gigi yang telah diakui oleh pemerintah dan lulus ujian sesuai dengan persyaratan yang berlaku".

2. Berdasarkan Peraturan Menteri Kesehatan Republik Indonesia Nomor 20 Tahun 2016 tentang Izin dan Penyelenggaraan Praktik Terapis Gigi dan Mulut adalah: "Perawat gigi adalah setiap orang yang telah lulus pendidikan perawat gigi sesuai dengan peraturan perundang-undangan yang berlaku".

Dari pengertian di atas dapat disimpulkan, perawat gigi adalah setiap orang yang telah lulus pendidikan perawat gigi yang diakui oleh pemerintah dan sesuai dengan perundang-undangan yang berlaku. Perawat gigi yang menjalankan tugasnya di saranan pelayanan kesehatan di seluruh Indonesia harus mempunyai SIPG dan SIK sesuai dengan Peraturan. Peraturan yang dimaksud yaitu Peraturan Menteri Kesehatan Republik Indonesia Nomor 20 Tahun 2016 tentang Izin dan Penyelenggaraan Praktik Terapis Gigi dan Mulut merupakan salah satu profesi 
kesehatan yang melaksanakan pelayanan asuhan kesehatan gigi dan mulut secara profesional dan di dalam melaksanakan tugasnya perawat gigi memiliki kewenangan hukum yang di dapat dari peraturan perundang-undangan yang berlaku.

Perawat gigi merupakan bagian integral dari keperawatan. Menurut hasil lokakarya Keperawatan Nasional tahun 1983, keperawatan adalah suatu bentuk pelayanan profesional yang merupakan bagian integral dari pelayanan kesehatan yang didasarkan pada ilmu dan kiat keperawatan, berbentuk bio-psiko-sosialspiritual yang komprehensif, ditujukan kepada individu, keluarga, masyarakat baik yang sakit maupun sehat dan mencakup seluruh siklus hidup manusia. Berdasarkan definisi di atas, dapat kita ketahui bahwa keperawatan merupakan bentuk pelayanan yang diberikan berdasarkan ilmu dan kaidah keperawatan ${ }^{5}$.

Secara khusus ketentuan untuk perawat gigi antara lain termuat di dalam Surat Keputusan Menteri Kesehatan Republik Indonesia Nomor 284/Menkes/SK/IV/2006 Tentang Standar Pelayanan Asuhan Kesehatan Gigi dan Mulut. Asuhan kesehatan gigi dan mulut adalah pelayan kesehatan gigi dan mulut yang terencana ditunjukkan kepada kelompok tertentu yang dapat diikuti dalam kurun waktu tertentu diselenggarakan secara berkesinambungan untuk mencapai kesehatan gigi dan mulut yang optimal.

Perawat gigi menjadi ujung tombak pembangunan kesehatan gigi Indonesia dan sebagai sumber daya manusia kesehatan gigi yang mempunyai peran sentral dalam asuhan kesehatan gigi yang merupakan barisan terdepan dalam aspek promotif dan preventif pelayanan gigi

\footnotetext{
${ }^{5}$ Sri Praptianingsih, 2006, Kedudukan Hukum Perawat Dalam Upaya Pelayanan Kesehatan di Rumah Sakit, Edisi 1, Jakarta, Raja Grafindo Persada, Hal. 25.
}

mulut. Peraturan Menteri Kesehatan Republik Indonesia Nomor 20 Tahun 2016 tentang Izin dan Penyelenggaraan Praktik Terapis Gigi dan Mulut digunakan sebagai pedoman dalam menjalankan profesi secara baik dengan tujuan sebagai berikut:

a. Memberikan pelayanan asuhan kesehatan gigi sesuai dengan tujuan, fungsi, dan wewenang yang dimilikinya.

b. Memberikan perlindungan kepada perawat gigi dari tuntutan hukum.

c. Memberikan perlindungan kepada masyarakat dari malpraktik perawat gigi.

Kemampuan inti dari seorang perawat gigi sebagai berikut:

a. Mampu menyuluh dalam upaya meningkatkan derajat kesehatan gigi dan mulut.

b. Mampu melakukan pelatihan kader kesehatan gigi.

c. Mampu membuat dan menggunakan media komunikasi upaya pencegahan penyakit gigi.

d. Mampu melakukan pemeriksaan gigi dan mulut.

e. Mampu menginstruksikan tehnik menyikat gigi yang baik.

f. Mampu melakukan skalling, melakukan pembersihan plak ekstrinsik staining dan kalkulus dan mampu melakukan topical aplikasi.

g. Mampu melakukan fissure sealant dan mampu memelihara kesehatan gigi dan mulut pasien umum rawat inap $^{6}$.

\section{Teori Pelimpahan Wewenang.}

Dalam Teori Pelimpahan Wewenang (sering juga disebut dengan kewenangan) adalah suatu tindakan hukum yang diatur dan diberikan kepada suatu jabatan berdasarkan peraturan perundangundangan yang berlaku mengatur jabatan

\footnotetext{
${ }^{6}$ Pakpahan, N., 2008, Standar profesi Perawat Gigi, http://www.rohukor.depkes.go.id /?art=26\&set=0.
} 
yang bersangkutan ${ }^{7}$. Kewenangan memiliki kedudukan penting dalam kajian hukum negara dan hukum administrasi negara, begitu pentingnya kewenangan ini, sehingga F.A.M Stroink dan J.G Steenbeek menyebutnya sebagai konsep inti dalam hukum tata negara dan hukum administrasi negara ${ }^{8}$

Menurut Lutfi kewenangan yang sah bila ditinjau dari segi sumber dari mana kewenangan itu lahir atau diperoleh, maka terdapat tiga kategori kewenangan yaitu:

1) Kewenangan atribusi atau kewenangan asli atau kewenangan yang tidak dibagibagikan kepada siapapun. Dalam kewenangan atribusi ini pelaksananya dilakukan sendiri oleh pejabat atau badan tersebut yang tertera dalam peraturan dasarnya. Adapun terhadap kewenangan atribisi mengenai tanggung jawab dan tanggung gugat berada pada pejabat atau pada badan sebagaimana tertera dalam peraturan dasarnya.

2) Kewenangan mandat, merupakan kewenangan yang bersumber dari proses atau prosedur pelimpahan dari pejabat atau badan yang lebih tinggi kepada pejabat atau badan yang lebih rendah.

3) Kewenangan delegasi, merupakan kewenangan yang bersumber dari pelimpahan suatu organ pemerintah kepada organ lain dengan dasar peraturan perundangundangan. Berbeda dengan kewenangan mandat, dalam kewenangan delegasi tanggung

\footnotetext{
${ }^{7}$ Habib Hadji, 2008, Hukum notaris indonesiaTafsir Tematik Terhadap UU no. 30 Tahun 2004 Tentang jabatan Notaris, Refika Aditama, Bandung, Hal. 77.

${ }^{8}$ Ridwan HR, 2013, Hukum Administrasi Negara, Raja Grafindo Persada, Jakarta, Hal. 99.
}

jawab dan tanggung gugat beralih kepada yang diberi limpahan wewenang tersebut atau beralih pada degelaris ${ }^{9}$.

Berdasarkan keterangan di atas, tampak bahwa kewenangan yang diperoleh secara atribusi itu bersifat asli yang berasal dari peraturan perundang-undangan, dengan kata lain organ pemerintahan memperoleh kewenangan secara langsung dari pasal tertentu dalam suatu peraturan perundang-undangan, jadi dalam atribusi , penerima wewenang dapat menciptakan wewenang baru atau memperluas wewenang yang sudah ada dengan tanggung jawab intern dan ekstern. Pada delegasi tidak ada penciptaan wewenang, yang ada hanya pelimpahan wewenang dari pejabat yang satu kepada pejabat yang lainnya, sehingga tanggungjawab yuridis tidak lagi berada pada pemberi delegasi (delegans) tetapi beralih pada penerima delegasi (delegaris). Sementara pada mandat penerima mandat (mandataris) hanya bertindak dan atas nama pemberi mandat (mandans), tanggung jawab akhir keputusan yang diambil oleh penerima mandat tetap berada pada pmberi mandat. Hal ini karena pada dasarnya penerima mandat ini bukan pihak lain dari pemberi mandat $^{10}$.

\section{Tindakan medik}

Berdasarkan Surat Keputusan Menteri Kesehatan Republik Indonesia Nomor 666 Tahun 2007 Tentang Klinik Rawat Inap Pelayanan Medik Dasar, yang dimaksud dengan pelayanan medik adalah pelayanan kesehatan individual yang dilandasi ilmu klinik (clinical science), merupakan upaya kesehatan perorangan yang meliputi aspek primer (promotif dan preventif), sekunder meliputi deteksi dini pengobatan serta

9 Lutfi Effendi, 2004, Pokok-pokok Hukum Administrasi, Cetakan III, Malang, Bayumedia, Hal. 77-79.

${ }^{10}$ Ridwan HR, 2013, Hukum Administrasi Negara, Raja Grafindo Persada, Jakarta, Hal. 105-106. 
pencegahan cacat dan tersier berupa rehabilitasi medik yang secara maksimal dilakukan oleh dokter, dokter gigi termasuk dokter keluarga.

Sesuai dengan Peraturan Pemerintah Nomor 32 Tahun 1996 disebutkan bahwa tenaga kesehatan adalah salah satunya terdiri dari tenaga medik dan tenaga keperawatan. Di dalam peraturan tersebut dijelaskan lebih lanjut bahwa tenaga medik terdiri dari dokter atau dokter gigi, sedangkan tenaga keperawatan terdiri dari bidan dan perawat, dalam hal ini sesuai dengan Peraturan Menteri Kesehatan Republik Indonesia Nomor 20 Tahun 2016 tentang Izin dan Penyelenggaraan Praktik Terapis Gigi dan Mulut menyatakan bahwa perawat gigi merupakan salah satu jenis tenaga kesehatan dalam kelompok keperawatan. Dalam hal ini tenaga medik terdiri dari dokter umum, dokter spesialis, dokter gigi non spesialis atau dokter gigi spesialis maka dari pembagian tersebut tindakan medik juga dapat dikelompokkan menjadi dua yaitu tenaga medik dasar dan tenaga medik spesialistik, dimana tindakan medik dasar dilakukan oleh dokter umum dan dokter gigi non spesialis. Dari pengertian di atas dapat disimpulkan bahwa tindakan medik adalah suatu tindakan yang dilakukan oleh dokter terhadap pasien berupa preventif, diagnosis, terapeutik dan rehabilitasi ${ }^{11}$.

Tindakan medik atau tindakan kedokteran lebih lanjut diatur di Peraturan Menteri Kesehatan Nomor 290 Tahun 2008 Tentang Persetujuan Tindakan Kedokteran, pada Pasal 1 angka 3 yaitu:

"Tindakan kedokteran atau kedokteran gigi yang selanjutnya disebut tindakan kedokteran adalah suatu tindakan medik berupa preventif, diagnostik, terapeutik atau rehabilitatif yang dilakukan oleh

11 Soewono,H., 2005, Batas Pertanggungjawaban Hukum Malpraktik Dokter Dalam Transaksi Terapeutik, Surabaya, Srikandi, Hal. 17. dokter atau dokter gigi terhadap pasien".

Tugas pokok memberikan pelayanan kesehatan berupa asuhan keperawatan dan didasarkan pada ilmu dan kiat keperawatan dan secara komprehensif, hal ini sesuai dengan Pasal 1 ayat (2) dan Pasal 4 Keputusan Menteri Pendayagunaan Aparatur Negara Nomor 94/KEP/M.PAN/II/ tahun 2001 Tentang Jabatan Fungsional Perawat dan Angka Kreditnya ditetapkan:

Pasal 1 ayat (2) :

"Pelayanan keperawatan adalah pelayanan kesehatan yang didasarkan pada ilmu dan kiat keperawatan yang mencangkup biopsikososio spiritual yang komprehensif, ditujukan kepada individu, keluarga, kelompok dan masyarakat, baik sakit maupun sehat yang meliputi peningkatan derajat kesehatan, pencegahan penyakit, penyembuhan dan pemulihan kesehatan dan menggunakan pendekatan proses keperawatan"

Pasal 4

"Tugas pokok perawat adalah memberikan pelayanan keperawatan berupa asuhan keperawatan/kesehatan kepada individu, keluarga, kelompok, dan masyarakat dalam upaya kesehatan, pencegahan penyakit, penyembuhan penyakit, dan pemulihan serta pembinaan peran serta masyarakat dalam rangka kemandirian di bidang keperawatan/kesehatan".

Berdasarkan Keputusan Menteri Pendayagunaan Aparatur Negara Nomor 94/KEP/M.PAN/II/ tahun 2001 Tentang 
Jabatan Fungsional Perawat dan Angka Kreditnya, tindakan keperawatan lebih bersifat komprehensif, menyangkut pelayanan bio-psikologi, sosial dan spiritual. Perawat menangani masalah secara fisik, psikologi seperti keyakinan untuk sembuh, menumbuhkan rasa optimis dan percaya diri pasien, serta perasaan dihargai. Perawat juga memenuhi aspek sosial seperti perasaan dibutuhkan, dicintai dan diperhatikan. Sementara pemenuhan kebutuhan spiritual dapat berupa memotivasi pasien untuk melakukan ibadah, membimbing pasien untuk bersabar ${ }^{12}$.

Dari pengertian di atas sudah jelas bahwa tindakan medik hanya dapat dilakukan oleh dokter atau dokter gigi hal ini sangat berbeda dengan tindakan keperawatan yang dilakukan oleh seorang perawat. Tindakan keperawatan lebih mengutamakan tindakan kebutuhan jasmani dan psikologis dari seorang pasien atau klien.

\section{Tanggung jawab hukum tenaga kesehatan}

Dalam pergaulan hidup manusia, setiap hari manusia itu selalu melakukan perbuatan-perbuatan untuk memenuhi kepentingannya. Segala perbuatan manusia yang secara sengaja dilakukan oleh seseorang untuk menimbulkan hakkewajiban dinamakan perbuatan hukum ${ }^{13}$. Ada juga yang mengartikan perbuatan hukum adalah perbuatan subyek hukum yang ditujukan untuk menimbulkan akibat hukum yang sengaja dikehendaki oleh subyek hukum ${ }^{14}$.

Dalam pengertian hukum tanggung jawab berarti keterikatan. Setiap manusia mulai dari saat ia dilahirkan sampai saat ia meninggal dunia mempunyai hak dan

${ }^{12}$ Sri Praptianingsih, 2006, Kedudukan Hukum Perawat Dalam Upaya Pelayanan Kesehatan di Rumah Sakit, Edisi 1, Jakarta, Raja Grafindo Persada, Hal. 30-31. kewajiban dan disebut subyek hukum. Demikian juga tenaga kesehatan khususnya perawat gigi dan dokter gigi, dalam melakukan suatu tindakan harus bertanggung jawab sebagai subyek hukum yang pengemban hak dan kewajiban.

Tindakan atau perbuatan tenaga kesehatan sebagai subyek hukum dalam pergaulan masyarakat, dapat dibedakan antara tindakan sehari-hari yang tidak berkaitan dengan profesi, dan tindakan yang berkaitan dengan profesinya. Begitu juga dalam tanggung jawab hukum seorang perawat gigi, dapat tidak berkaitan dengan profesi, dan dapat pula merupakan tanggung jawab hukum yang berkaitan dengan pelaksanaan profesinya.

Perbuatan dokter yang tidak berkaitan dengan pelaksanaan profesi yang menimbulkan tanggung jawab hukum antara lain: menikah, melakukan perjanjian jual-beli, membuat wasiat dan sebagainya. Perbuatan tenaga kesehatan yang tidak berkaitan dengan pelaksanaan profesinya ini, pada umumnya juga bisa dilakukan oleh setiap orang yang bukan tenaga kesehatan.

Tanggung jawab hukum yang timbul berkaitan dengan pelaksanaan profesi tenaga kesehatan merupakan tanggung jawab hukum yang harus dipenuhi dokter yang pada dasarnya meliputi 3 (tiga) bentuk pertanggungjawaban yaitu:

1. Bidang hukum administrasi yang terdapat di Undang-Undang Nomor 29 tahun 2004 Tentang Praktik Kedokteran, Undang-Undang Nomor 36 tahun 2009 Tentang Kesehatan, Surat Keputusan Menteri Kesehatan Nomor 1392 Tahun 2001 Tentang Registrasi dan Izin Perawat Gigi.

2. Bidang hukum pidana, terdiri dari:

13 Kansil, 1989, Pengantar Ilmu Hukum dan Tata Hukum Indonesia, Cetakan 8, Jakarta, Balai Pustaka, Hal. 119.

14 Sudikno M, 1986, Mengenal Hukum, Yogyakarta, Liberty, Hal. 42. 

a. Kitab Undang-Undang Hukum Pidana.
b. Ketentuan Pidana dalam Undang-Undang Nomor 36 tahun 2009 Tentang Kesehatan.
c. Ketentuan Pidana dalam Undang-Undang Nomor 29 tahun 2004 Tentang Praktik Kedokteran.

3. Bidang hukum perdata, terdiri dari:

a. Buku III BW tentang Hukum Perikatan.

b. Undang-Undang Nomor 8 tahun 1999 Tentang Perlindungan Konsumen ${ }^{15}$.

\section{PEMBAHASAN}

Perawat gigi selain memiliki kewenangan juga dalam memberikan pelayanan keperawatan harus sesuai dengan kompetensi yang diperoleh selama pendidikan, menurut Keputusan Konsil Kedokteran Indonesia (KKI) Nomor 23 tahun 2006 Tentang Pengesahan Standar Kompetensi Dokter Gigi, yang dimaksud dengan kompetensi adalah seperangkat kemampuan profesional yang meliputi penguasaan ilmu pengetahuan, ketrampilan dan nilai-nilai (knowledge, skill dan attitude), dalam melaksanakan tugas profesionalnya.

Berdasarkan tingkatan pendidikan yang ada maka kemampuan, keilmuan dan sikap profesionalnya juga berbeda-beda. Beban tugas dan kewenangannya juga berbeda-beda sehingga tidak semua perawat gigi mampu menerima pelimpahan wewenang dari dokter gigi dalam mengerjakan tindakan medik terbatas. Sampai penelitian ini dilakukan belum ada peraturan perundangundangan yang mengakomudasi perbedaan jenjang pendidikan di keperawatan gigi dan tidak semua perawat gigi memilki kemampuan yang sama, padahal kemampuan pendidikan mereka tidak sama.

\footnotetext{
${ }^{15}$ Isfandyarie. A., 2006, Tanggung Jawab Hukum dan Sanksi bagi Dokter Buku I, Cetakan 1, Jakarta, Prestasi pustaka, Hal. 5-6.
}

Berdasarkan pengertian kompetensi di atas unsur-unsur ilmu pengetahuan, ketrampilan dan nilai-nilai diperoleh selama pendidikan. Kewenangan perawat gigi, terlihat bahwa kompetensi yang diperoleh selama pendidikan belum ada disebutkan tindakan medik terbatas dalam bidang kedokteran gigi sehingga dapat dikatakan bahwa kompetensi yang diperoleh oleh perawat gigi tidak sesuai dengan kewenangan atribusi yang terlihat dalam Surat Keputusan Menteri Kesehatan Nomor 378 Tahun 2007 Tentang Standar Profesi Perawat Gigi maupun sesuai dengan ketentuan hukum yaitu Peraturan Menteri Kesehatan Republik Indonesia Nomor 20 Tahun 2016 tentang Izin dan Penyelenggaraan Praktik Terapis Gigi dan Mulut. Untuk menyikapi hal tersebut seharusnya kurikulum pendidikan yang diberikan harus mengacu kepada Keputusan Menteri Kesehatan Nomor 378 Tahun 2007 Tentang Standar Profesi Perawat Gigi yang dipersyaratkan sehingga sesuai dengan kewenangan perawat gigi.

Perawat gigi memilki kewenangan untuk melakukan pelayanan kesehatan apa bila mereka telah memilki surat izin dari pemerintah ${ }^{16}$. Hal ini sesuai dengan UndangUndang Nomor 36 Tahun 2009 Tentang Kesehatan Pasal 23 ayat (3) yang berbunyi, dalam menyelenggarakan pelayanan kesehatan, tenaga kesehatan wajib memiliki izin dari pemerintah.

Tanggung jawab hukum yang timbul berkaitan dengan pelaksanaan profesi tenaga kesehatan merupakan tanggung jawab hukum yang harus dipenuhi dokter yang pada dasarnya meliputi 3 (tiga) bentuk pertanggungjawaban yang pertama hukum administrasi yang termuat dalam UndangUndang Nomor 29 tahun 2004 Tentang Praktik Kedokteran, Undang-Undang Nomor 36 tahun 2009 Tentang Kesehatan, Surat Keputusan Menteri Kesehatan Nomor 1392 Tahun 2001 Tentang Registrasi dan Izin Perawat Gigi. Kedua hukum pidana, terdiri dari; Kitab

16 Wila Chandrawila Supriadi, 2001, Hukum Kedokteran, Bandung, Mandar Maju, hal. 52. 
Undang-Undang Hukum Pidana, UndangUndang Nomor 36 tahun 2009 Tentang Kesehatan, Undang-Undang Nomor 29 tahun 2004 Tentang Praktik Kedokteran. Ketiga hukum perdata, terdiri dari; Buku III BW tentang Hukum Perikatan.

Berdasarkan ilmu hukum administrasi negara pada kewenangan delegasi, tanggung jawab dan tanggung gugat beralih kepada yang diberi limpahan wewenang atau beralih kepada delegaris ${ }^{17}$. Pelimpahan wewenang yang dilakukan oleh dokter gigi memberikan pelimpahan wewenang kepada perawat gigi sesuai dengan kemampuan pendidikan, kompetensi dan standar profesi yang dimiliki oleh perawat gigi. Hal ini sesuai dengan Peraturan Menteri Kesehatan Republik Indonesia Nomor 512/Menkes/Per/IV/2007 Tentang Izin Praktik dan Pelaksanaan Praktik Kedokteran, pada Pasal 15 yang berbunyi sebagai berikut:

(1) Dokter dan dokter gigi dapat memberikan pelimpahan suatu tindakan kedokteran atau kedokteran gigi kepada perawat, bidan atau tenaga kesehatan tertentu lainnya secara tertulis dalam melaksanakan tindakan kedokteran atau kedokteran gigi.

(2) Tindakan kedokteran atau kedokteran gigi sebagaimana dimaksud pada ayat (1) harus sesuai dengan kemampuan dan kompetensi yang dimiliki dan dilaksanakan sesuai ketentuan peraturan perundang-undangan.

Pada Pasal 15 ayat (2) disebutkan bahwa apabila dokter gigi dengan sengaja melakukan pelimpahan sebagian wewenangnya secara delegasi yang tidak sesuai dengan batas kewenangan perawat gigi maka akan mendapatkan sanksi disiplin, administrasi, perdata dan pidana karena melanggar peraturan perundang-undangan.

\footnotetext{
${ }^{17}$ Ridwan, 2010, Hukum Administrasi Negara, Jakarta, Rajawali Press, hal. 109.
}

Penerapan Surat Keputusan Menteri Kesehatan Nomor 1392 Tentang Registrasi dan Izin Kerja Perawat Gigi seorang perawat gigi bisa melakukan tindakan asuhan keperawatan gigi dan mulut serta tindakan medik terbatas dalam bidang kedokteran gigi berdasarkan pelimpahan dari dokter gigi. Kewenangan mandiri dilakukan oleh perawat gigi tanpa harus ada pelimpahan dari dokter gigi, karena secara hukum perawat gigi memilki kewenangan atribusi untuk melakukan tindakan tersebut. Kewenangan mandiri dari perawat gigi adalah tindakan keperawatan kedokteran gigi dan dalam keadaan tertentu dimana tidak ada dokter gigi dan tenaga perawat sangat dibutuhkan maka tindakan medik terbatas dalam bidang kedokteran gigi menjadi wewenang dari perawat gigi. Dalam melakukan tindakan yang menjadi kewenangan mandiri perawat gigi tanggung jawab ada di perawat gigi dan tanggung gugat bisa dilakukan secara tanggung renteng.

Tugas limpah yang diberikan oleh dokter gigi kepada perawat gigi harus dilakukan secara tertulis dan pelimpahan ini telah dilakukan sesuai dengan kemampuan pendidikan dan standar profesi perawat gigi maka apabila ada tuntutan hukum di bidang pidana maka yang bertanggung jawab adalah perawat gigi yang melakukan tindakan tersebut. Berdasarkan hukum pidana barang siapa yang berbuat maka dia yang bertanggung jawab, sehingga pelimpahan wewenangan secara delegasi maka tanggung jawab dan tanggung gugat beralih kepada yang diberi limpahan wewenang atau kepada delegaris. Sehingga apabila di dalam melakukan pelayanan kesehatan diduga ada malpraktik maka tanggung jawab atas keselahan yang dilakukan berpindah kepada perawat gigi. Adapun tanggung gugat bisa dilakukan tanggung renteng mulai dari perawat gigi, Kepala Puskesmas, Dinas Kesehatan Kota Salatiga sampai Walikota Salatiga. 
Pelimpahan sebagian wewenang dokter gigi kepada perawat gigi apabila terjadi kesalahan dalam proses pelimpahan maka yang bertanggung jawab dan tanggung gugat adalah yang memberi limpahan. Kesalahan ini bisa terjadi misalnya pelimpahan dilakukan secara tidak tertulis, tidak sesuai kemampuan, pendidikan dan standar profesi perawat gigi. Kenyataan dilapangan selama pengamatan yang dilakukan oleh peneliti dan dari data-data yang dikumpulkan pelimpahan wewenang ini tidak pernah dilakukan secara tertulis hal ini didasarkan juga data dilapangan bahwa tidak ditemukan data tentang pelimpahan sebagian wewenang secara tertulis dari dokter gigi kepada perawat gigi tetapi perawat gigi melakukan tindakan medik terbatas di bidang kedokteran gigi.

\section{PENUTUP}

Kewenangan tenaga kesehatan dalam memberikan pelayanan kesehatan merupakan kewenangan hukum ${ }^{18}$. Menurut van Wijk, F.A.M. Stroink dan J.G. Steenbeek dalam Ridwan menyebutkan bahwa hanya ada dua cara organ pemerintahan dalam hal ini perawat gigi yang bekerja di Puskesmas memperoleh wewenang, yaitu atribusi dan delegasi ${ }^{19}$. Berdasarkan penjelasan di atas maka kewenangan perawat gigi dalam melakukan upaya pelayanan kesehatan keperawatan memiliki dua kewenangan yaitu kewenangan atribusi dan kewenangan delegasi. Kewenangan yang diperoleh baik secara atribusi maupun delegasi harus sesuai dengan standar profesi tenaga kesehatan tersebut. Hal ini sesuai dengan Peraturan Menteri Kesehatan Republik Indonesia Nomor 20 Tahun 2016 tentang Izin dan Penyelenggaraan Praktik Terapis Gigi dan Mulut.

Proses pelimpahan wewenang yang dilakukan oleh dokter gigi kepada perawat gigi di Puskesmas sebagai subyek hukum tentunya ada konsekuensi-konsekuensi hukum yang berlaku, terutama bila wewenang yang dilakukan menimbulkan dampak negatif atau

18 Wila Chandrawila Supriadi, 2001, Hukum Kedokteran, Bandung, Mandar Maju, hal. 52. adanya dugaan kesalahan dalam pelaksanaan pelayanan kesehatan. Sanksi yang bisa diberikan kepada dokter gigi maupun perawat gigi bisa berupa sanksi disiplin, administrasi, perdata dan pidana.

\section{DAFTAR PUSTAKA}

Admosudirjo,S. P, 1995, Hukum Administrasi Negara, Cetakan 10, Jakarta, Ghalia Indonesia

Habib Hadji, 2008, Hukum notaris indonesiaTafsir Tematik Terhadap UU no. 30 Tahun 2004 Tentang jabatan Notaris, Refika Aditama, Bandung

Isfandyarie. A., 2006, Tanggung Jawab Hukum dan Sanksi bagi Dokter Buku I, Cetakan 1, Jakarta, Prestasi pustaka

Kansil, 1989, Pengantar Ilmu Hukum dan Tata Hukum Indonesia, Cetakan 8, Jakarta, Balai Pustaka.

La OdeJumadi G., 1999, Pengantar Keperawatan Profesional,Cetakan 1, Jakarta, EGC

Lutfi Effendi, 2004, Pokok-pokok Hukum Administrasi, Cetakan III, Malang, Bayumedia

Pakpahan, N., 2008, Standar profesi Perawat Gigi,http://www.rohukor.depkes.go.id.

Ridwan, 2010, Hukum Administrasi Negara, Jakarta, Rajawali Press.

Soewono,H., 2005, Batas

Pertanggungjawaban Hukum

Malpraktik Dokter Dalam Transaksi

Terapeutik, Surabaya, Srikandi.

Sri Praptianingsih, 2006, Kedudukan Hukum

Perawat Dalam Upaya Pelayanan

Kesehatan di Rumah Sakit, Edisi 1, Jakarta, Raja Grafindo Persada,

Sudikno M, 1986, Mengenal Hukum, Yogyakarta, Liberty,

Wila Chandrawila Supriadi, 2001, Hukum Kedokteran, Bandung : Mandar Maju.

\footnotetext{
${ }^{19}$ Ridwan, 2010, Hukum Administrasi Negara, Jakarta, Rajawali Press, hal. 105.
} 
AJUDIKASI : Jurnal Ilmu Hukum, Vol. 2 No. 1, Juni 2018. Hlm 67-80 